\title{
A Randomized Trial Comparing Desarda repair no Mesh and Lichtenstein repair for inguinal hernia (A study of 2225 patients)
}

\author{
PRL Rodriguez*1, OCL Gonzàlez ${ }^{1}$, JS Rocha ${ }^{1}$, PP Herrera ${ }^{2}$, EG Castillo ${ }^{3}$, AD Casanova ${ }^{4}$ and LMD Fundora ${ }^{3}$ \\ ${ }^{1}$ Auxiliary Proffessor in General Surgery, Enrique Cabrera National Hospital, Cuba
}

${ }^{2}$ Professor in General Surgery, Enrique Cabrera National Hospital, Cuba

${ }^{3}$ Asistent Proffessorin General Surgery, Enrique Cabrera National Hospital, Cuba

${ }^{4}$ General Surgeon, Enrique Cabrera National Hospital, Cuba

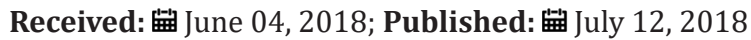

*Corresponding author: Pedro Rolando López Rodríguez, Enrique Cabrera“National Hospital, Boyeros, Havana, Cuba, Continental Street No. 152 between D’Strampes Street and Goicuría Street, Sevillano, 10 de Octubre, Havana, Cuba

\begin{abstract}
Introduction: The objective of this study is to compare the outcomes of Desarda repair no mesh and Lichtenstein repair for inguinal hernia. Patients and

Methods: This is a prospective randomized controlled trial study of 2225 patients having 2336 hernias operated from January 2002 to December 2016.1150 patients were operated using Lichtenstein repair and1075 using Desarda repair. The variables like age, sex, location, type of hernia, tolerance to local anesthesia, duration of surgery, pain on the first, third and fifth day, hospital stay, complications, re-explorations, morbidity and time to return to normal activities were analyzed. Follow up period was from 1-10 years (median 6.5 years).

Results: There were no significant differences regarding age, sex, location, type of hernia, and pain in both the groups. The operation time was 51 minutes in Desarda group and 40 minutes in the Lichtenstein group that is significant $(\mathrm{p}<0.05)$. The recurrence was $0.6 \%$ in Desarda group and 0.4 $\%$ in Lichtenstein group. But, there were 11 cases of infection to the polypropylene mesh in the Lichtenstein group, 6 of this required re-exploration. The morbidity was also significantly more in Lichtenstein group $(6,0 \%)$ as compared to Desarda group (3.6 \%). The mean time to return to work in the Desarda group was 8.26 days while a mean of 12.58 days was in the Lichtenstein group. The mean hospital stay was 29 hrs. In Desarda group while it was 49 hours in the Lichtenstein group in those patients who were hospitalized.Conclusions: Desarda repair scores significantly over the Lichtenstein repair in all respects including re-explorations and morbidity. Desarda repair is a better choice as compared with Lichtenstein repair.

Keywords: Lichtenstein Repair; Desarda Repair; Inguinal Hernia; Randomized Trial
\end{abstract}

\section{Introduction}

The surgeons use different techniques in Cuba for inguinal hernia repair like Bassini or Shouldice and its modifications or different types of mesh repairs. The standard mesh is not available at many places and it is expensive also. Hernia treatment has become a health problem because of its social, economic and labor implications due to its high incidence in our population [1]. Until recently, the only parameters to be evaluated were recurrence, complication rates etc. Today, other parameters like cost, postsurgerywellbeing and quality of life have gained importance. The demand of general surgeons is to identify operations that are simple to perform without the need for complicated dissection and with low complication and recurrence rates. Avoidance of use of foreign material where possible is a basic surgical principal.The authors read about the Desarda repair which seems be simple in concept, avoids the use of mesh and gives the desired results. This repair is based on the concept of providing a strong and physiologically dynamic posterior wall to the inguinal canal.

An undetached strip of the aponeurosis of the external oblique muscle replaces the absent aponeurotic element in the posterior wall and the weakened conjoint muscle receives additional strength from the external oblique muscle to keep it physiologically dynamic [2].There are still many controversies to answer. Which is the best technique for repair?[3] Is hernioplasty better than herniorrhaphy? Which is the best technique for hernioplasty or herniorrhaphy? Does laparoscopic surgery have a better cost-efficiency than open surgery? Is mesh necessary in all inguinal hernia repairs?The 
objective of this study is to re-evaluate the Lichtenstein mesh repair and compare it with the novel and "No mesh, physiological repair" described by Desarda.

\section{Methods}

A prospective randomized controlled trial was carried out in 2225 patients having 2336 hernias operated from January 2002 to December 2016. 1150 patients having 1226 hernias were in the Lichtenstein group and 1075 patients having 1110 hernias in the Desarda group. All the patients from both sexes older than 16 years with primary and recurrent inguinal hernias were included. Patients operated on emergency basis were excluded. The diagnosis of inguinal hernia and its type was made by clinical examination. Information was given to the patients as regards the anesthetic procedures. The patient chose type of anaesthesia after discussion with the surgeon. The Randomization was performed using a consecutively numbered, sealed envelope, which was opened, in theatre and all patients having an even number were operated by the Lichtenstein and uneven numbers by the Desarda technique. The operating surgeon completed a data sheet. The operating surgeon was at consultant level for all operations. The evaluator was also a surgeon of consultant level. All patients signed a written informed consent. Approval of the local ethical committee was given prior to the onset of the study.

Desarda repair was performed according to the surgical technique described by Dr. Desarda and mesh prosthesis repair was undertaken as described in the textbooks. Prophylactic antibiotic was administered in the operating room before surgery (Cefazoline 1g.) in the Lichtenstein group only. All patients were discharged as soon as their post-surgical recovery allowed and all patients were instructed to do daily, routine, non-strenuous work after discharge.A non-steroidal anti-inflammatory (Diclofanac) analgesic was prescribed for a period of 5 days and continued if required. The consultants followed all the patients at 8 days, 1 month, 6 months and then yearly thereafter.A data sheet was completed by the operating surgeon including type of hernia (Nyhus classification) [4], anaesthesia, technical details and intraoperative complications. At discharge, further data was added including any early post-operative complications. Patients were asked to complete a pain score on the first, third and fifth day after surgery using a linear analogue scale [5,6]. At first follow up, one month after surgery, further data were collected including time to return to normal activities. The Student $\mathrm{T}$ test was used to compare the independent measures and the Mann Whitney-U test for nonparametric data. The Chi-squared test and Fisher's exact test were used to measure the association between quality variables.

\section{Results}

There was no significant difference in relation to sex, age, location and type of inguinal hernia in both the groups. Table1 Local anesthesia was used in 497 patients in Lichtenstein group and 700 patients in the Desarda group. All those 1142 (51.3\%) patients were operated on as outpatient basis without hospitalization. In the remainder of 819 patients who were treated as in-patients, the mean hospital stay was 29 hours in Desarda group and 49 hours in the Lichtenstein group $(\mathrm{p}<0.05)$
(Table 2). Tolerance to local anesthesia was good during surgery in $68 \%$ and $67 \%$ respectively (NS). The mean duration of surgery was 40 minutes for Lichtenstein and 51 minutes for Desarda group $(\mathrm{p}<0.05)$. Analysis of pain scores from day one to day 5 showed no significant difference (Table 3). There was no incidence of severe pain in either group. The recurrence rate was $0.6 \%$ in the Desarda group, and $0.4 \%$ in the Lichtenstein group (NS). Five patients in the Lichtenstein group required re-exploration and mesh removal for the sepsis. Thus $0.4 \%$ of patients in the Lichtenstein group required a further surgical intervention for either recurrence or sepsis which was significantly higher than the Desarda group $(\mathrm{p}<0.05)$ (Table 4). $66(6.0 \%)$ patients developed post-operative complications in the Lichtenstein group and37 (3.4\%) patients showed complications in the Desarda group $(\mathrm{p}<0.05)$ (Table 5). 73,0 \% patients returned to work within 8-15 days in the Desarda group with a mean of 13,4days while 55,4\% patients returned to work within 8-15 days with a mean of 14.5 days in the Lichtenstein group, that is significant because in the Lichtenstein group the morbidity is higher than in the Desarda group $(p<0.05)$ (Table 6). There was no case of chronic groin pain lasting for more than 6 months in either of the groups. Follow up was complete in over $97 \%$ at 1 year, $92 \%$ at 2 years, $89 \%$ at 3 years, $83 \%$ at 4 years, $80 \%$ at 5 years, $80 \%$ at 6 years, $76 \%$ at 7 years, $73 \%$ at 8 years, $72 \%$ at 9 years and $70 \%$ at 10 years with no significant difference between the two operation groups.

Table 1: AGE, SEX, Location and type of hernia.

\begin{tabular}{|c|c|c|c|c|}
\hline \multirow{3}{*}{$\begin{array}{c}\text { Age Sex } \\
\text { Location } \\
\text { Median Age: }\end{array}$} & \multicolumn{4}{|c|}{ Surgical Technique } \\
\hline & \multicolumn{2}{|c|}{$\begin{array}{l}\text { Lichtenstein Group } \\
\text { n=1150 }\end{array}$} & \multicolumn{2}{|c|}{$\begin{array}{c}\text { Desarda Group } \\
\mathbf{n = 1 0 7 5}\end{array}$} \\
\hline & 57.4 & & 58.2 & \\
\hline & No. & $\%$ & No. & $\%$ \\
\hline \multicolumn{5}{|l|}{ Sex } \\
\hline Male & 1077 & 93.6 & 1002 & 93 \\
\hline Female & 73 & 6.4 & 73 & 7 \\
\hline \multicolumn{5}{|l|}{ Location } \\
\hline Right & 552 & 48 & 530 & 49,3 \\
\hline Left & 522 & 45.4 & 510 & 47.4 \\
\hline Bilateral & 76 & 6,6 & 35 & 3.3 \\
\hline \multicolumn{5}{|l|}{$\begin{array}{l}\text { Type of } \\
\text { Hernia }\end{array}$} \\
\hline $\begin{array}{c}\text { I, } \\
\text { sSSSSSSSSSSSSSSSS }\end{array}$ & 499 & 43.4 & 532 & 49.8 \\
\hline IIIa, IIIb & 567 & 49,3 & 497 & 46.2 \\
\hline IV & 84 & 7.3 & 46 & 4 \\
\hline
\end{tabular}

Table 2: Anesthesia and hospital stay.

\begin{tabular}{|c|c|c|c|c|}
\hline \multirow{3}{*}{$\begin{array}{l}\text { Anesthesia } \\
\text { and } \\
\text { Hospitalstay }\end{array}$} & \multicolumn{4}{|c|}{ Surgical Technique } \\
\hline & \multicolumn{2}{|c|}{$\begin{array}{c}\text { Lichtenstein } \\
\text { Groupn=1150 }\end{array}$} & \multicolumn{2}{|c|}{$\begin{array}{c}\text { Desarda Group } \\
\mathbf{n = 1 0 7 5}\end{array}$} \\
\hline & No. & $\%$ & No. & $\%$ \\
\hline \multicolumn{5}{|c|}{ Anesthesia } \\
\hline Local & 497 & 43,2 & 700 & 65,2 \\
\hline Spinal & 580 & 50,4 & 350 & 32,6 \\
\hline General & 73 & 6,4 & 25 & 2.2 \\
\hline
\end{tabular}




\begin{tabular}{|c|c|c|c|c|}
\hline \multicolumn{5}{|c|}{ Hospitalization } \\
\hline $\begin{array}{c}\text { Out door } \\
\text { surgery } \\
\text { without } \\
\text { hospitalization }\end{array}$ & 473 & 41,0 & 699 & 65,0 \\
\hline $\begin{array}{c}\text { Short Term } \\
\text { Hospitalization } \\
(<3 \text { days })\end{array}$ & 585 & 51,0 & 363 & 33,7 \\
\hline $\begin{array}{c}\text { Long Term } \\
\text { Hospitalization } \\
(>3 \text { days })\end{array}$ & 92 & 8,0 & 13 & 1,3 \\
\hline
\end{tabular}

$\underline{\text { Table 3: }}$ Duration of Surgery and Pain.

\begin{tabular}{|c|c|c|c|c|}
\hline \multirow{2}{*}{$\begin{array}{l}\text { Duration } \\
\text { Tolerance } \\
\text { And pain }\end{array}$} & \multicolumn{4}{|c|}{ Surgical Technique } \\
\hline & \multicolumn{2}{|c|}{$\begin{array}{l}\text { Lichtenstein Group } \\
\qquad \mathbf{n}=\mathbf{1 1 5 0}\end{array}$} & \multicolumn{2}{|c|}{$\begin{array}{l}\text { Desarda Group } \\
\text { n= } 1075\end{array}$} \\
\hline \multicolumn{5}{|c|}{ Duration of Surgery: } \\
\hline \multirow[t]{2}{*}{ Average } & $40 \mathrm{mts}$ & & $\begin{array}{c}51 \mathrm{mtsP}< \\
0.01\end{array}$ & \\
\hline & No. & $\%$ & No. & $\%$ \\
\hline \multicolumn{5}{|c|}{ Pain: Mild to Moderate } \\
\hline First Day & 616 & 53.6 & 646 & 60.1 \\
\hline Up to Third Day & 410 & 35.6 & 337 & 31.6 \\
\hline Up to Fifth Day & 124 & 10.8 & 92 & 8.3 \\
\hline
\end{tabular}

There was no incidence of severe pain or chronic groin pain in both the groups.

Table 4: Recurrence and re-exploration.

\begin{tabular}{|c|c|c|c|c|}
\hline $\begin{array}{c}\text { Lichtenstein } \\
\text { Group } \\
\text { N1150 }\end{array}$ & $\begin{array}{c}\mathbf{5} \text { Mesh } \\
\text { removal } \\
\text { For sepsis }\end{array}$ & $\mathbf{0 . 4 0 \%}$ & $\begin{array}{c}\mathbf{5} \\
\text { Recurrence }\end{array}$ & $\mathbf{0 . 4 0 \%}$ \\
\hline $\begin{array}{c}\text { Desarda } \\
\text { Group }\end{array}$ & - & & 6 & $0.60 \%$ \\
N 1075 & & & Recurrence & \\
\hline
\end{tabular}

Table 5: Morbidity.

\begin{tabular}{|c|c|c|c|c|c|c|}
\hline \multirow{2}{*}{ Morbidity } & \multicolumn{5}{|c|}{ Surgical Technique } \\
\cline { 2 - 7 } & \multicolumn{2}{|c|}{ Lichtenstein Group } & \multicolumn{2}{c|}{ Desarda Group } & \multicolumn{2}{c|}{ TOTAL } \\
\cline { 2 - 7 } & No. & $\mathbf{\%}$ & No. & \% & No. & \% \\
\hline Seroma & 15 & 1,3 & 7 & 0.7 & 22 & 1,0 \\
\hline $\begin{array}{c}\text { Mild } \\
\text { infection }\end{array}$ & 11 & 1,0 & 8 & 0.8 & 19 & 0,8 \\
\hline Hematoma & 9 & 0,8 & 6 & 0.6 & 15 & 0.7 \\
\hline Orchitis & 7 & 0.6 & 4 & 0.4 & 11 & 0.5 \\
\hline $\begin{array}{c}\text { Testicular } \\
\text { atrophy }\end{array}$ & 4 & 0.3 & - & - & 4 & 0.2 \\
\hline $\begin{array}{c}\text { Sepsis } \\
\text { without re- } \\
\text { exploration }\end{array}$ & 6 & 0,5 & - & - & 6 & 0.3 \\
\hline $\begin{array}{c}\text { Sepsis } \\
\text { with re- } \\
\text { exploration }\end{array}$ & 4 & 0.3 & - & - & 4 & 0.2 \\
\hline Bradycardia & 5 & 0,4 & 6 & 0.6 & 11 & 0.5 \\
\hline Recurrence & 5 & 0.4 & 6 & 0.6 & 11 & 0.5 \\
\hline \begin{tabular}{c} 
TOTAL \\
\hline
\end{tabular} & 66 & 6,0 & 37 & 3.4 & 103 & 4.6 \\
\hline
\end{tabular}

Table 6: Return to Work.

\begin{tabular}{|c|c|c|c|c|}
\hline \multirow{2}{*}{$\begin{array}{c}\text { Patients } \\
\text { Returned } \\
\text { towork }\end{array}$} & \multicolumn{3}{|c|}{ Surgical Technique } \\
\cline { 2 - 5 } & \multicolumn{2}{|c|}{ Lichtenstein Group } & \multicolumn{2}{c|}{ Desarda Group } \\
\cline { 2 - 5 } & No. & $\%$ & \multicolumn{2}{c|}{ n= 1075 } \\
\hline 1 - 7 Days & 36 & 3,1 & 70 & $\%$ \\
\hline 8 - 15 Days & 637 & 55.4 & 785 & 73,0 \\
\hline 16 - 30 Days & 477 & 41.5 & 220 & 20,5 \\
\hline
\end{tabular}

Lichtenstein Group: Mean :1-7 days: 6,8 days ,8-15 days : 14,5 days , 16-30 days : 21,3 days.

Desarda Group: Mean:1-7 days : 5,7 days, 8-15 days : 13,4 days, 16-30 days : 18,4 days.

\section{Discussion}

Mesh repair is now widely used in the developed world and is often referred to as the gold standard despite a relative paucity of clinical trials comparing mesh with suture repair. The cost of surgery [7] and the post-operative morbidity affecting the quality of life are important considerations in the inguinal hernia surgery. There are no clear scientific evidences to prove that the mesh prosthetic repair is superior to the non-prosthetic repair in this respect [8]. There are advantages and disadvantages associated with all types of open inguinal hernia repairs. Existing non-prosthetic repair (Bassini/Shouldice) is blamed causing tissue tension and mesh prosthetic repair is blamed for known complications of a foreign body. Dr. Desarda sutures an undetached strip of the external oblique aponeurosis between the muscle arch and the inguinal ligament to give a strong and physiologically dynamic posterior wall [9]. This results in a tension free repair without the use of any foreign body. Being simple to perform it eliminates disadvantage of technical difficulty seen with Shouldice repair.

Different studies have tried to give an answer as to which of the existing operation is best for inguinal hernia repair $[10,11]$. The EU Hernia Trialist collaboration [12] made a systematic revision of the randomized prospective studies and the analysis of the results of these different studies. It showed that the duration of surgery was less in hernioplasty in six studies, longer in three and equal in the remaining six. In our group, there was a significant but slight increase in operating time with the Desarda operation. Postoperative pain after mesh prosthetic repair may be less than after Shouldice repair because of reduced tension $[12,13]$. Our results have shown that there are no significant differences between the two groups for pain on the first to fifth day after surgery. We found no significant difference in analgesic requirements between the techniques. Overall morbidity was $5.0 \%$, which is similar to the rates described in other studies (7-12\%) [14]. The morbidity rate was higher after the Lichtenstein repair (53 cases, $7.5 \%$ versus $26,3.4 \%$ in the Desarda group). There were 8 mesh infections after surgery in the Lichtenstein group. Two cases required partial excision of the mesh and in one case, it was associated with recurrence. Desarda technique has lower morbidity as compared to mesh hernioplasty.

We believe that the four cases of recurrences seen in Desarda group were due to failure of proper lateralization of the cord and insufficient narrowing of the internal ring as advised by Desarda.

Cite this article: PRLRodriguez, OCL Gonzàlez, JS Rocha, PP Herrera, EG Castillo, et al. A Randomized Trial Comparing Desarda repair no mesh and Lichtenstein repair for inguinal hernia (A study of 2225 patients). Biomed J Sci \& Tech Res 6(4)- 2018. BJSTR. MS.ID.001396. DOI: 10.26717/ BISTR.2018.06.001396. 
This was evident at re-exploration in those cases that needed only narrowing of the internal ring with few more stitches. In patients admitted to hospital, post-operative stay and the period required to return to normal work after surgery was also significantly in favour of the Desarda group. 62 patients from Lichtenstein group required more than 3 days in the hospital due to local wound complications or for some other reasons compared to only 5 patients from the Desarda group, a significant difference. We noted a marked difference in the type of anaesthetic used 39\% v 72\% for local, $54 \%$ v $25 \%$ for spinal and $7 \%$ v $2 \%$ for general anaesthetic in Lichtenstein $v$ Desarda group. This could affect the statistics of hospital stay of the patients who required hospitalization.

The external oblique muscle technique satisfies all criteria of modern hernia surgery. It is simple and easy to do. It does not require risky or complicated dissection. There is minimal tension in the suture line. It does not require any foreign material and it does not use weak muscle or fascia transversalis for repair. It does not use mesh prosthesis so it is more economical. No foreign body is required in the Desarda repair thus avoiding morbidity associated with foreign bodies including rejection, infection and chronic groin pain. Jacek Szopinski etal. [15] stated in their randomized controlled trial (RCT) that the "Desarda technique has the potential to enlarge the number of tissue based methods available to treat groin hernias. The most evident indications for use of the Desarda technique include use in young patients, in contaminated surgical fields, in the presence of financial constraints, or if a patient disagrees with the use of mesh."Situma et al. [16] compared Desarda technique with the modified Bassini technique in their RCT and concluded that there is no difference in short-term outcome between Desarda and modified Bassini inguinal hernia repair as regards resumption of normal gait and patterns of pain.

Manyilirah [17] concluded in their RCT that the efficacy of the Desarda technique in respect of the early clinical outcomes of hernia repair is similar to that of Lichtenstein method. However the operator in this study showed that the Desarda repair takes a significantly shorter operative time $[18,19]$. The authors therefore conclude that the Desarda repair for inguinal hernia gives the same or better results when compared with the Lichtenstein Mesh repair with shorter hospital stay, more rapid recovery and avoidance of specific mesh related complications whilst also reducing the cost of surgery. It is technically simpler than the Shouldice repair and we recommend that surgeons become acquainted with this technique $[20,21]$.

\section{References}

1. Rutkow MI (1998) Epidemiologic, economic and sociologic aspects of hernia surgery in the United States in the 1900s. Surg North Am 78(6): 941-951.

2. Desarda MP (2001) Inguinal herniorrhaphy with an undetached strip of external oblique aponeurosis: a new approach used in 400 patients. Eur J Surg 167(6): 01-06.

3. Porrero JL (2005) Reparación de la hernia inguinal primaria: Lichtenstein frente a Shouldice. Estudio prospectivo y aleatorizado sobre el dolor y los costos hospitalarios. Cir Esp 77(2): 5-8.
4. Aragon FJ (2001) Nuevas técnicas protésicas para el tratamiento de la hernia inguinal. Ediciones Avila p. 22-23.

5. Price DD, Bush FM, Long S Harkins SW (1994) A comparison of pain measurement characteristics of mechanical visual analogue and simple numerical rating scales. Pain 56(2): 217-226.

6. PorreroJL, Sanchez-Cabezudo C, Lee P (1998) Study of unilateral post-herniorrhaphy analgesia with local anaesthetic and monitored anaesthesia care. Ambulatory Surg 6: 211-214.

7. Costos hospitalarios (2005) Comunicación personal. Departamento económico. Hospital Enrique Cabrera Enero.

8. Porrero JL (1999) El cambio de la cirugía de la hernia en la última década. In: Celdran A, de la Pinta JC (Eds.). Fundamentos de la hernioplastia sin tensión. Madrid: Fundación Jiménez Díaz p. 9-11.

9. MP Desarda (2003) Surgical physiology of inguinal hernia repair-a study of 200 cases. BMC Surgery 3: 1-9.

10. Simons MP, Kifignen J, Van Geldere D, Hoitsma HFW, Obertop H (1996) Role of the Shouldice technique in inguinal hernia repair: a systematic review of controlled trials and meta-analysis. Br J Surg 83(6): 734-738.

11. McGillicuddy JE (1998) Prospective randomized comparison of the Shouldice and Lichtenstein hernia repair procedures. Arch Surg 133(9): 974-978.

12. EU Hernia Trialist Collaboration (2000) Mesh compared with non-mesh methods of open groin hernia repair: systematic review of randomized controlled trials. Br J Surg 87(7): 854-859.

13. Kingsnorth AN, Porter Chs, Bennett DH, Walker AJ, Hyland ME, et al. (2000) Lichtenstein patch or prefix plug and patch in inguinal hernia: a prospective double-blind randomized controlled trial of short-term outcome. Surgery 127(3): 276-283.

14. Gilbert AI, Felton IL (1993) Infection on inguinal hernia repair considering biomaterials and antibiotics. Surg Gynecol 117(2): 126-130.

15. Jacek Szopinski, Stanislaw Dabrowiecki, Stanislaw Pierscinski, Marek Jackowski, Maciej Jaworski, et al. (2012) Desarda Versus Lichtenstein Technique for Primary Inguinal Hernia Treatment: 3-Year Results of a Randomized Clinical Trial. World J Surg 36(5): 984-992.

16. SM Situma, S Kaggwa, NM Masiira, SK Mutumba (2009) Comparison of Desarda versus Modified Bassini inguinal Hernia Repair: A Randomized controlled trial. East Cent Afr J surg 14(2): 70-76.

17. Manyilirah W, Kijjambu S, Upoki A, Kiryabwire J (2012) Comparison of non-mesh (Desarda) and mesh (Lichtenstein) methods for inguinal hernia repair among black African patients: a short-term double-blind RCT. Hernia 16(2): 133-144.

18. Yousset T, El-Alfy K, Farid M (2015) Randomized Clinical trial of primary inguinal hernia. Int J Surg 20: 28-34.

19. Dieng M, Cisse M, Seek M, Diallo FK, Tourè AD, et al. (2012) Cure des hernies inguinales simples de L' adulte pastie avec L' aponèurose du grand oblique: Technique de Desarda. e-mèmoires de L'Acadèmie Nationale de Chirurgie 11(2): 069-074.

20. Jianxin Z, Dong JW, Zhiyong Z (2013) Desarda inguinal hernia repair and synthetic patch (open VS TEP) hernia repair comparative study. J Chinese Her and abdominal Surg 7(6): 559-563.

21. Lòpez Roduìguez PR, Pol Herrera PG, Lèon Gonzàlez OC, Cruz Alonso JR, Rodrìguez Blanco HS (2013) A Randomized Trial Comparing Lichtenstein repair and no mesh Desarda repair for inguinal Hernia: A Study of 1382 patients. East Cent Afr J Surg. 


\section{ISSN: 2574-1241}

DOI: 10.26717/BJSTR.2018.06.001396

Pedro Rolando López Rodríguez. Biomed J Sci \& Tech Res

(c) (i) This work is licensed under Creative

Submission Link: https://biomedres.us/submit-manuscript.php

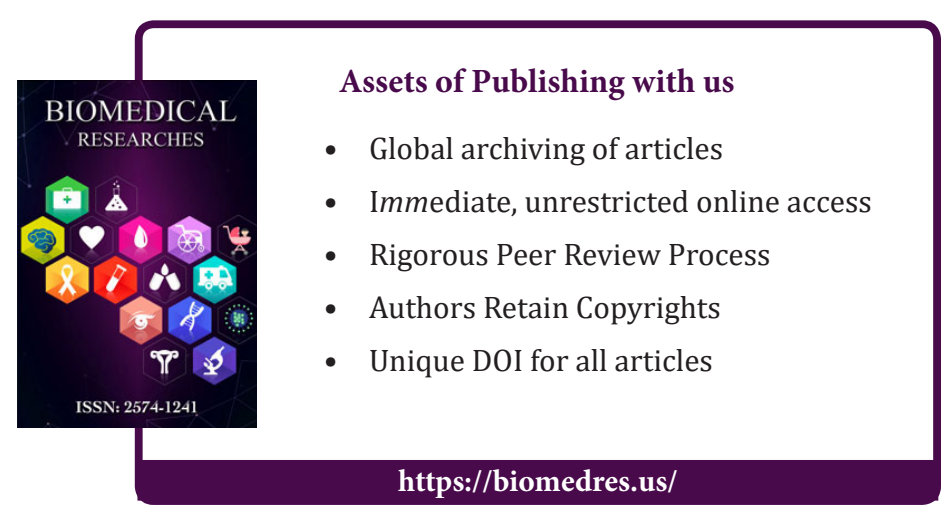

